\title{
Pengembangan Lembar Kegiatan Mahasiswa (LKM) Kalkulus Berbantuan Software Geogebra untuk Meningkatkan Kemampuan Spasial
}

\author{
Wilda Syam Tonra*1, Astuti Salim ${ }^{2}$ \\ ${ }^{1,2}$ Universitas Khairun \\ e-mail: ${ }^{1}$ wilda@unkhair.ac.id ${ }^{2}$ thytin_thobona@yahoo.com
}

\begin{abstract}
Abstrak
Penelitian pengembangan ini mengacu pada model pengembangan perangkat 4-D (Four D Model) yang bertujuan untuk: (1) Mengetahui kualitas LKM mata kuliah kalkulus berbantuan software geogebra yang telah dihasilkan (2) Mengetahui ada atau tidak ada perbedaan kemampuan spasial mahasiswa sebelum dan sesudah pemberian LKM berbantuan software GeoGebra (3) Memberikan gambaran seberapa besar peningkatan kemampuan spasial mahasiswa berbantuan software GeoGebra dengan menggunakan LKM pada mata kuliah Kalkulus. Subjek penelitian adalah mahasiswa pendidikan fisika semester II kelas A tahun 2018 Universitas Khairun. Rancangan penelitian menggunakan one-group pretest posttest design. Analisis hasil penelitian menggunakan teknik analisis deskriptif dan inferensial. Hasil penelitian menunjukkan bahwa (1) Perangkat pembelajaran yang telah dikembangkan dalam penelitian ini menurut hasil validasi pakar adalah berkualitas baik sehingga layak untuk digunakan (2) terdapat peningkatan kemampuan spasial setelah diberikan perlakuan menggunakan SPSS 20 analisis uji pairet $t$ test. (3) peningkatan kemampuan spasial setelah diberikan LKM berbantuan software GeoGebra adalah berkategori sedang menggunakan analisis onesample test.
\end{abstract}

Kata kunci: Four-D Model, Lembar Kerja Mahasiswa (LKM), Software GeoGebra

\section{PENDAHULUAN}

Piaget dan Inhelder (1956) menyebutkan bahwa kemampuan spasial sebagai konsep abstrak yang di dalamnya meliputi hubungan spasial (kemampuan untuk mengamati hubungan posisi objek dalam ruang), kerangka acuan (tanda yang dipakai sebagai patokan untuk menentukan posisi objek dalam ruang), hubungan proyektif (kemampuan untuk melihat objek dari berbagai sudut pandang), konservasi jarak (kemampuan untuk memperkirakan jarak antara dua titik), representasi spasial (kemampuan untuk merepresentasikan hubungan spasial dengan memanipulasi secara kognitif), rotasi mental (membayangkan perputaran objek dalam ruang)

Konsep kemampuan spasial digunakan untuk kemampuan yang berhubungan dengan penggunaan ruang menurut Olkun (2003) atau mengacu pada keterampilan dalam. Mewakili, mengubah, menghasilkan dan mengingat simbolis informasi nonlinguistik dalam Linn dan Petersen (1985). Contohnya, Menurut Tartre (1990) kemampuan spasial adalah keterampilan mental yang bersangkutan dengan memahami, 
memanipulasi, menata ulang atau menafsirkan hubungan secara visual. Selain itu, Lohman (1993) menyatakan bahwa kemampuan spasial mungkin ada didefinisikan sebagai kemampuan untuk menghasilkan, mempertahankan, mengambil dan mentransformasikan yang terstruktur gambar visual dan definisi yang lebih komprehensif dinyatakan oleh Battista dan Clements (1998) sebagai kemampuan untuk merumuskan citra mental dan untuk memanipulasi gambar-gambar ini di dalam pikiran. Keberadaannya berbeda definisi memicu perbedaan definisi komponen spasial kemampuan. Pertama, McGee (1979) menyatakan bahwa kemampuan spasial memiliki dua prinsipal Faktor; Visualisasi spasial dan orientasi spasial. Visualisasi spasial mengacu pada kemampuan rotasi mental, memanipulasi, dan memutar dua dan tiga dimensi. Selanjutnya kemampuan spasial adalah kemampuan untuk membangun, mempertahankan, mengambil, dan memanipulasi citra visual objek dua dan tiga dimensi dalam Lohman (1993).

\section{METODE PENELITIAN}

LKM Penelitian pengembangan ini mengacu pada model pengembangan perangkat 4-D (Four D Model) yang terdiri atas 4 tahap yaitu pertama. (1) Tahap pendefinisian yang terdiri dari analisis awal akhir, analisis mahasiswa, analisis materi, analisis tugas, spesifikasi tujuan pembelajaran. (2) Tahap perancangan yaitu pemilihan media, pemilihan format, perancangan awal perangkat pembelajaran. Pada tahap inilah LKM draft-1 telah dihasilkan. (3) Tahap pengembangan meliputi validasi ahli dan uji coba. Rancangan uji coba perangkat pembelajaran menggunakan one-group pretest posttest design

Tabel 1 Rancangan uji coba (one-group pretest posttest design)

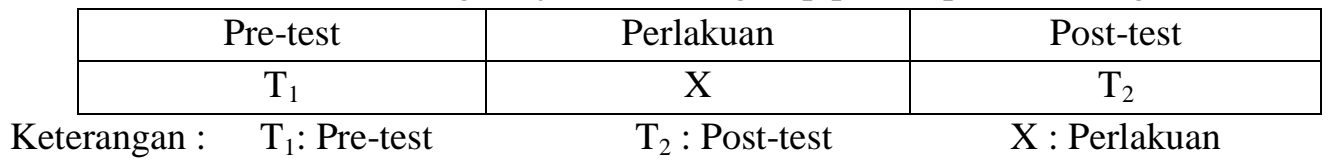

Tahap penyebaran. Pada tahap ini, LKM final yang telah dikembangkan akan digunakan oleh mahasiswa Program Studi Pendidikan Fisika mata kuliah kalkulus pada angkatan berikutnya.

\subsection{Analisis Data}

Data yang diperoleh dalam penelitian ini meliputi hasil telaah LKM, dan tes kemampuan spasial. Adapun data-data tersebut akan dianalisis secara deskriptif kuantitatif. LKM yang sudah divalidasi akan dianalisis untuk melihat kualitas LKM dan dikonversikan pada tabel kriteria kualitas LKM sebagai berikut: 
Tabel 2 Kriteria Kualitas LKM

\begin{tabular}{|c|c|c|}
\hline Interval & SKOR RATA-RATA & KRITERIA \\
\hline $\bar{x}+1,5 S D i<x \leq \bar{x}+3 S D i$ & $3,25<x \leq 4$ & $\begin{array}{c}\text { SANGAT } \\
\text { BAIK/SESUAI }\end{array}$ \\
\hline $\bar{x}+0,5 S D i<x \leq \bar{x}+1,5 S D i$ & $2,75<x \leq 3,25$ & BAIK \\
\hline $\bar{x}-0,5 S D i<x \leq \bar{x}+0,5 S D i$ & $2,25<x \leq 2,75$ & CUKUP \\
\hline $\bar{x}-1,5 S D i<x \leq \bar{x}-0,5 S D i$ & $1,75<x \leq 2,25$ & KURANG SESUAI \\
\hline $\bar{x}-3 S D i<x \leq \bar{x}-1,5 S D i$ & $1<x \leq 1,75$ & $\begin{array}{c}\text { SANGAT TIDAK } \\
\text { BAIK/SESUAI }\end{array}$ \\
\hline
\end{tabular}

Dengan : $\bar{x}=1 / 2(4+1)=2,5$ dan SDi $=(4-1) / 6=0,5$

Selain itu, untuk menilai validitas isi LKM dan instrumen kemampuan spasial ditentukan dengan menggunakan kesepakatan para ahli. Kesepakatan ahli diukur untuk melihat tingkatan validitas isi oleh rumus Aiken yaitu:

Keterangan:

$\mathrm{V}=$ indeks validitas butir, $\mathrm{s}=\mathrm{r}-\mathrm{I}_{\mathrm{o}}=$ skor kategori pilihan rater - skor terendah dalam kategori penyekoran, $\mathrm{n}=$ banyak rater, $\mathrm{c}=$ banyak kategori yang dipilih.

Selanjutnya hasil indeks validitas tersebut dikonversikan pada tabel kriteria validitas yaitu:

Tabel 3 Kriteria Validitas

\begin{tabular}{|c|c|}
\hline Interval & Kriteria \\
\hline $0,90 \leq V<1,00$ & Sangat tinggi (sangat baik) \\
\hline $0,70 \leq V<0,90$ & Tinggi (baik) \\
\hline $0,40 \leq V<0,70$ & Sedang (cukup) \\
\hline $0,20 \leq V<0,40$ & Rendah (kurang) \\
\hline $0,00 \leq V<0,20$ & Sangat rendah (kurang) \\
\hline$\leq 0,00$ & Tidak valid \\
\hline
\end{tabular}

\subsection{Analisis Inferensial}

Analisis inferensial ini bertujuan untuk menjawab rumusan masalah yang kedua yaitu apakah ada perbedaan sebelum dan sesudah pemberian LKM terhadap kemampuan spasial mahasiswa. analisis ini menggunakan SPSS 20 uji pairet t test. Dengan H0: tidak ada perbedaan sebelum dan sesudah pemberian LKM terhadap kemampuan spasial mahasiswa. H1: ada perbedaan sebelum dan sesudah pemberian LKM terhadap kemampuan spasial mahasiswa Kriteria pengambilan keputusan :

Jika sig > 0.05 maka H0 diterima. Jika sig < 0.05 maka H0 ditolak 


\section{2..3 Analisis Deskriptif}

Analisis statistik deskriptif digunakan untuk menjawab rumusan masalah ketiga. Rumus yang digunakan adalah Gain $\langle g\rangle=\frac{\mathrm{S}_{\text {post }}-\mathrm{S}_{\text {pre }}}{\mathrm{S}_{\text {maks }}-\mathrm{S}_{\text {pre }}}$. Kriteria Gain menurut (Hake, 1999) disajikan dalam tabel berikut:

Tabel 4 Kriteria N-Gain

\begin{tabular}{|c|c|}
\hline Interval & Interpretasi \\
\hline$g>0,7$ & Tinggi \\
\hline $0,3<g<0,7$ & Sedang \\
\hline$g<0,3$ & Rendah \\
\hline
\end{tabular}

Berikut adalah ringkasan alur penelitian pengembangan LKM

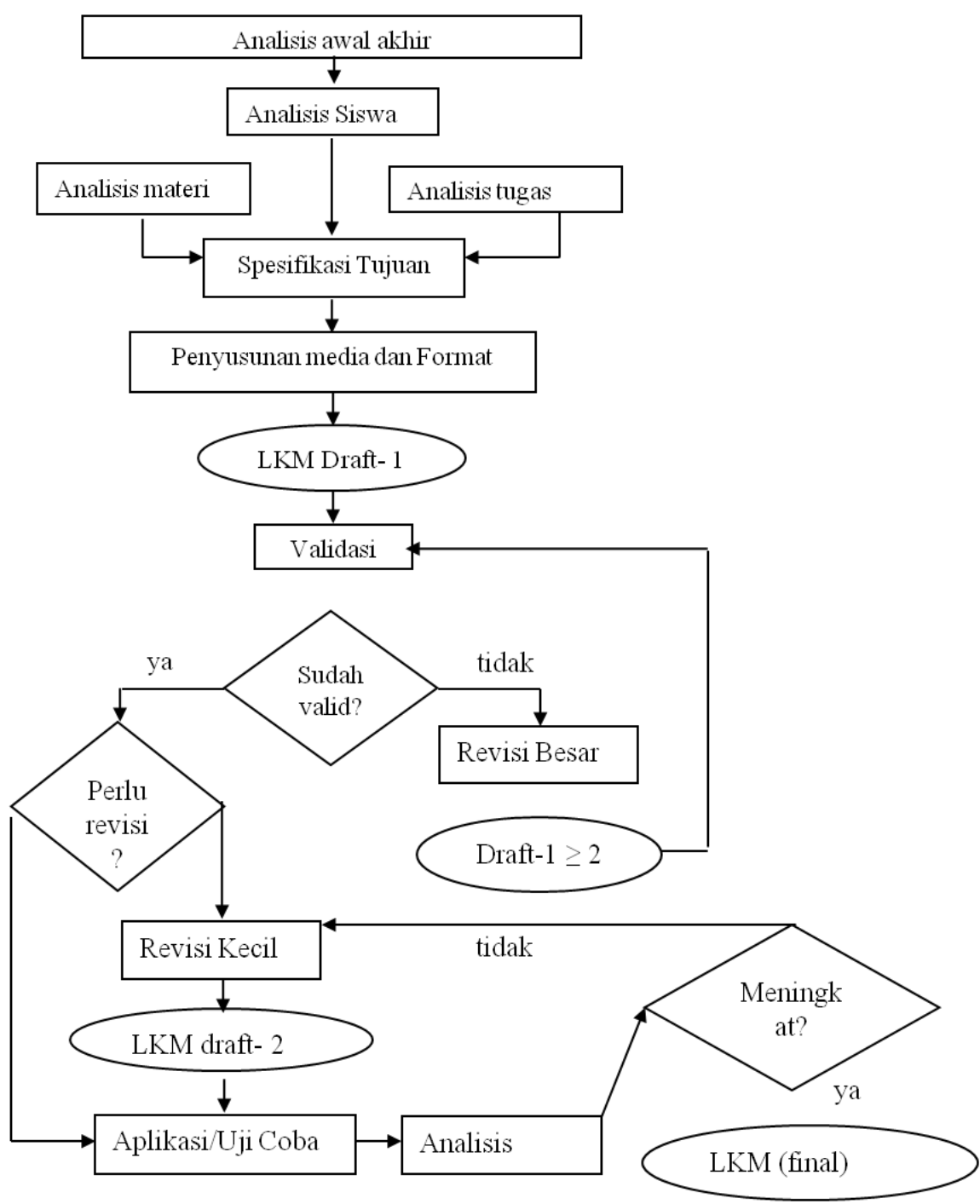

Gambar 1 Alur Kegiatan Pengembangan LKM Mata Kuliah Kalkulus Berbantuan Software Geogebra Untuk Meningkatkan Kemampuan Spasial Mahasiswa 


\section{HASIL DAN PEMBAHASAN}

\subsection{Tahap Pendefinisian}

\subsubsection{Analisis awal-akhir}

Berdasarkan hasil pengamatan dan wawancara beberapa mahasiswa, peneliti menemukan bahwa selama ini proses pembelajaran di kelas masih didominasi oleh metode ceramah, dosen pengampuh hanya memberikan teori berupa teorema dan juga hanya memberikan latihan soal menyangkut teorema di papan tulis. Mahasiswa belum diberikan tugas berupa Lembar Kerja Mahasiswa (LKM) pada mata kuliah kalkulus I. Oleh karena itu perlu disusun dan dikembangkan perangkat pembelajaran yang sesuai dan menunjang pelaksanaan pembelajaran sehingga dalam penelitian ini dikembangkan perangkat pembelajaran berupa Lembar Kerja Mahasiswa (LKM).

\subsubsection{Analisis Mahasiswa}

Mahasiswa yang dianalisis dalam penelitian ini adalah mahasiswa prodi pendidikan fisika kelas A tahun 2017

1. Kemampuan awal yang dimiliki oleh kelas A berbeda-beda. Ada yang menonjol dan ada yang biasa saja. Informasi ini didapat dari dosen pengampuh pada semester sebelumnya dengan memberikan pula nilai mata kuliah kalkulus I pada semester sebelumnya.

2. Bahasa yang digunakan dalam kelas sebagian besar menggunakan pasar Ternate. Walaupun dalam pembelajaran di kelas saat diskusi dengan guru menggunakan Bahasa Indonesia.

3. Motivasi mahasiswa terhadap mata kuliah masih tergolong baik. Mahasiswa cukup antusias menerima mata kuliah yang diberikan. Informasi ini diperoleh dari dosen pengampuh MK kalkulus I semester sebelumnya.

4. Rata-rata umur mahasiswa di Kelas A adalah 18-21 tahun karena ada beberapa siswa yang dulu pernah menganggur kemudian memutuskan untuk kuliah.

\subsubsection{Analisis Materi}

Materi ajar kalkulus II yang diberikan treatment adalah luas daerah dan volume benda putar. Berikut adalah rincian materi ajar :

\section{Luas Daerah}

a. Luas daerah di atas sumbu $\mathrm{x}$ dihitung dengan rumus integral:

$$
L=\int_{a}^{b} f(x) d x
$$

b. Luas daerah di bawah sumbu $\mathrm{x}$ dihitung dengan rumus integral tukar posisi $\mathrm{a}$ dan $\mathrm{b}$ :

$$
L=\int_{b}^{a} f(x) d x
$$

c. Jika kurva berada di atas dan di bawah sumbu x atau sebaliknya, maka tambahkan kedua luas daerah.

d. Jika kurva berada di atas, di bawah, dan di atas sumbu $\mathrm{x}$ atau sebaliknya, maka tambahkan ketiga luas daerah. 
2. Volume Benda Putar

a. Volume benda putar yang mengelilingi sumbu $\mathrm{x}$

b. Volume benda putar yang mengelilingi sumbu $y$

c. Volume benda putar dari daerah antara dua kurva yang diputar terhadap sumbu $\mathrm{x}$

d. volume benda putar dari daerah antara dua kurva yang diputar terhadap sumbu y

\subsubsection{Analisis Tugas}

1. Materi ajar tentang luas daerah

a. Mampu mendefinisikan kembali pengertian luas daerah di atas dan di bawah sumbu $\mathrm{X}$

b. Mampu menyelesaikan masalah terkait luas daerah di atas atau dibawah kurva sumbu X

c. Mampu menentukan luas daerah jika kurva berada di atas dan di bawah sumbu $\mathrm{X}$ atau sebaliknya

d. Mampu menentukan luas daerah jika berada pada dua kurva

e. Mampu menggunakan software GeoGebra dalam membantu memvisualisasikan grafik fungsi

f. Setelah menggunakan bantuan software Geogebra, mahasiswa mampu menggambar grafik dan menunjukkan luas daerah suatu fungsi

2. Materi ajar tentang Volume benda putar

a. Mampu mendefinisikan kembali pengertian volume benda putar

b. Mampu menyelesaikan masalah terkait volume benda putar yang mengelilingi sumbu X dan sumbu Y

c. Mampu menentukan volume benda putar dari daerah antara dua kurva yang diputar terhadap sumbu $\mathrm{x}$ atau sumbu y

d. Mampu menggunakan software GeoGebra untuk membantu memvisualisasikan grafik fungsi

e. Setelah menggunakan bantuan software Geogebra, mahasiswa mampu mengilustrasikan benda putar berdasarkan bangun datar yang diketahui

\subsection{Spesifikasi Tujuan Pembelajaran}

Spesifikasi tujuan pembelajaran sesuai dengan materi pada analisis tugas

\subsubsection{Tahap Perancangan}

a. Dasar penyusunan tes mengacu pada analisis tugas, analisis materi, dan spesifikasi tujuan pembelajaran. LKM dibuat kisi-kisi dan acuan penskoran setiap butir soal

b. Pemilihan Media, media yang diperlukan dalam pelaksanaan pembelajaran adalah software Geogebra versi 5.0. GeoGebra ini sangat membantu memvisualisasikan materi ajar yang berupa grafik sehingga diharapkan mampu meningkatkan kemampuan spasial mahasiswa.

c. Pemilihan Format, format Lembar Kerja Mahasiswa (LKM) yang digunakan disesuaikan dengan kebutuhan. Pada LKM tercantum indikator, dan petunjuk menyelesaikan latihan soal pada LKM. Isi pembelajaran mengacu pada hasil analisis 
konsep, hasil analisis tugas, dan spesifikasi tujuan pembelajaran yang telah dirumuskan pada tahap pendefinisian. Format Lembar Kerja Mahasiswa (LKM) dibuat dengan warna yang beragam dengan berbagai konten grafik didalamnya agar mahasiswa termotivasi untuk mengerjakannya. Di bawah setiap pertanyaan diberikan tempat untuk menuliskan jawaban.

d. Perancangan Awal . Pada tahap ini dihasilkan 4 rancangan LKM yaitu : LKM 1, LKM 2, LKM 3 dan LKM 4. Namun setelah menganalisis jumlah pertemuan di semester ini tidak akan mencukupi jika LKM dibagi menjadi 4 bagian. Sehingga diputuskan LKM 1 dan 2 digabung menjadi LKM-1 kemudian LKM 3 dan LKM 4 digabung menjadi LKM-2.

\subsubsection{Tahap Pengembangan}

a. Hasil validasi ahli

Kualitas Lembar Kerja Mahasiswa (LKM) Aljabar

LKM yang digunakan dalam penelitian ini berupa permasalahan menyangkut luas daerah dan volume benda putar yang dilengkapi dengan langkah-langkah menggunakan GeoGebra sebagai media yang digunakan dalam proses belajar LKM terdiri dari dua yaitu LKM-1 tentang luas daerah dan LKM-2 untuk volume benda putar. Sebelum digunakan dalam penelitian, LKM tersebut dievaluasi atau di validasi oleh 3 orang ahli untuk melihat kualitas dari LKM tersebut apakah layak digunakan atau tidak. Lembar validasi LKM dan instrumen tes terdiri dari 3 aspek yang dinilai oleh validator yaitu (1) format yang terdiri dari 6 butir (item); (2) isi, terdiri dari 5 butir (item); dan (3) bahasa yang terdiri dari 6 butir (item). Hasil perhitungan nilai rata-rata per butir dengan kriterianya dapat dilihat pada tabel berikut.

Tabel 7 Kriteria Kualitas LKM-1 per Butir

\begin{tabular}{|c|c|c|c|c|c|c|c|}
\hline \multirow{2}{*}{$\mathrm{No}$} & \multirow{2}{*}{ Aspek yang Dinilai } & \multicolumn{4}{|c|}{ Penilaian } & \multirow{2}{*}{$\begin{array}{l}\text { Rata } \\
\text {-rata }\end{array}$} & \multirow[t]{2}{*}{ kriteria } \\
\hline & & & $\mathrm{V} 1$ & V2 & V3 & & \\
\hline $\mathrm{I}$ & FORMAT & & & & & & \\
\hline & 1. Jenis huruf dan spasi & 4 & 3 & 4 & & 3,666667 & $\begin{array}{l}\text { Sangat } \\
\text { baik/sesuai }\end{array}$ \\
\hline & 2. Pengaturan tata letak & 4 & 3 & 4 & & 3,666667 & $\begin{array}{l}\text { Sangat } \\
\text { baik/sesuai }\end{array}$ \\
\hline & $\begin{array}{l}\text { 3. Memiliki daya tarik untuk dibaca dan } \\
\text { diselesaikan }\end{array}$ & 4 & 4 & 3 & & 3,666667 & $\begin{array}{l}\text { Sangat } \\
\text { baik/sesuai }\end{array}$ \\
\hline & 4. Pemilihan warna & 4 & 4 & 4 & & 4 & $\begin{array}{l}\text { Sangat } \\
\text { baik/sesuai }\end{array}$ \\
\hline & 5. Sistem penomoran & 3 & 4 & 4 & & 3,666667 & $\begin{array}{l}\text { Sangat } \\
\text { baik/sesuai }\end{array}$ \\
\hline & $\begin{array}{l}\text { 6. Kesesuaian antara soal dan ilustrasi } \\
\text { gambar }\end{array}$ & 3 & 4 & 4 & & 3,666667 & $\begin{array}{l}\text { Sangat } \\
\text { baik/sesuai }\end{array}$ \\
\hline
\end{tabular}




\begin{tabular}{|c|c|c|c|c|c|c|c|}
\hline \multirow{2}{*}{$\mathrm{No}$} & \multirow{2}{*}{ Aspek yang Dinilai } & \multicolumn{4}{|c|}{ Penilaian } & \multirow{2}{*}{$\begin{array}{l}\text { Rata } \\
\text {-rata }\end{array}$} & \multirow[t]{2}{*}{ kriteria } \\
\hline & & & $\mathrm{V} 1$ & $\mathrm{~V} 2$ & $\mathrm{~V} 3$ & & \\
\hline $\mathrm{II}$ & ISI YANG DISAJIKAN & & & & & & \\
\hline & 7. LKM disajikan secara sistematis & 4 & 3 & & 4 & 3,666667 & $\begin{array}{l}\text { Sangat } \\
\text { baik/sesuai }\end{array}$ \\
\hline & 8. Materi sesuai indikator & 4 & 3 & & 4 & 3,666667 & $\begin{array}{l}\text { Sangat } \\
\text { baik/sesuai }\end{array}$ \\
\hline & $\begin{array}{l}\text { 9. Masalah yang diangkat dapat } \\
\text { meningkatkan kemampuan spasial }\end{array}$ & 3 & 4 & & 4 & 3,666667 & $\begin{array}{l}\text { Sangat } \\
\text { baik/sesuai }\end{array}$ \\
\hline & $\begin{array}{l}\text { 10. Setiap kegiatan yang disajikan mempunyai } \\
\text { tujuan yang jelas }\end{array}$ & 4 & 4 & & 3 & 3,666667 & $\begin{array}{l}\text { Sangat } \\
\text { baik/sesuai }\end{array}$ \\
\hline & $\begin{array}{l}\text { 11. Kegiatan yang disajikan dapat } \\
\text { menumbuhkan } \\
\text { rasa ingin tahu siswa }\end{array}$ & 4 & 3 & & 3 & 3,333333 & $\begin{array}{l}\text { Sangat } \\
\text { baik/sesuai }\end{array}$ \\
\hline & $\begin{array}{l}\text { 12. Penyajian LKM dilengkapi dengan gambar } \\
\text { dan ilustrasi }\end{array}$ & 3 & 4 & & 4 & 3,666667 & $\begin{array}{l}\text { Sangat } \\
\text { baik/sesuai }\end{array}$ \\
\hline II & BAHASA & & & & & & \\
\hline & 13. Penggunaan bahasa sesuai EYD & 4 & 4 & & 3 & 3,666667 & $\begin{array}{l}\text { Sangat } \\
\text { baik/sesuai }\end{array}$ \\
\hline & $\begin{array}{l}\text { 14. Bahasa yang digunakan tidak bermakna } \\
\text { ambigu }\end{array}$ & 4 & 3 & & 3 & 3,333333 & $\begin{array}{l}\text { Sangat } \\
\text { baik/sesuai }\end{array}$ \\
\hline & 15. Bahasa yang digunakan komunikatif & 4 & 3 & & 4 & 3,666667 & $\begin{array}{l}\text { Sangat } \\
\text { baik/sesuai }\end{array}$ \\
\hline & $\begin{array}{l}\text { 16. Kalimat yang digunakan jelas,dan mudah } \\
\text { dimengerti }\end{array}$ & 4 & 4 & & 4 & 4 & $\begin{array}{l}\text { Sangat } \\
\text { baik/sesuai }\end{array}$ \\
\hline & 17. Kejelasan petunjuk atau arahan & 4 & 4 & & 3 & 3,666667 & $\begin{array}{l}\text { Sangat } \\
\text { baik/sesuai }\end{array}$ \\
\hline
\end{tabular}

Keterangan : V adalah validator. Cara menentukan kriteria kualitas LKM-2 seperti pada LKM-1

Berdasarkan tabel di atas yang berkriteria sangat baik/sesuai, dapat disimpulkan bahwa LKM-1 dan LKM-2 layak untuk digunakan. Selanjutnya untuk melihat kualitas LKM, adapun hasil kesepakatan ahli untuk melihat tingkat validitas LKM-1 dan LKM-2 dengan menghitung indeks validitas dapat ditunjukkan pada tabel berikut: 
Tabel 9 Kriteria Validitas

\begin{tabular}{|c|c|c|c|c|}
\hline Butir & LKM-1 & Kriteria & LKM-2 & Kriteria \\
\hline 1 & 0,888889 & Baik & 1 & Baik \\
\hline 2 & 0,888889 & Baik & 0,888889 & Baik \\
\hline 3 & 0,888889 & Baik & 0,777778 & Baik \\
\hline 4 & 1 & Sangat baik & 1 & Sangat baik \\
\hline 5 & 0,888889 & Baik & 1 & Baik \\
\hline 6 & 0,888889 & Baik & 1 & Baik \\
\hline 7 & 0,888889 & Baik & 0,888889 & Baik \\
\hline 8 & 0,888889 & Baik & 1 & Baik \\
\hline 9 & 0,888889 & Baik & 0,888889 & Baik \\
\hline 10 & 0,888889 & Baik & 0,888889 & Baik \\
\hline 11 & 0,777778 & Baik & 0,777778 & Baik \\
\hline 12 & 0,888889 & Baik & 0,666667 & Cukup \\
\hline 13 & 0,888889 & Baik & 0,888889 & Baik \\
\hline 14 & 0,777778 & Baik & 0,777778 & Baik \\
\hline 15 & 0,888889 & Baik & 0,777778 & Baik \\
\hline 16 & 1 & Sangat baik & 1 & Sangat baik \\
\hline 17 & 0,888889 & Baik & 0,888889 & Baik \\
\hline
\end{tabular}

Dari tabel diatas, terlihat penilaian dari ketiga validator terkait kualitas LKM berkriteria baik dan sangat baik yang menunjukkan bahwa kualitas LKM-1 dan LKM-2 dapat atau layak digunakan. Berdasarkan hasil tersebut, rumusan masalah pertama pada penelitian ini yaitu bagaimana kualitas LKM mata kuliah kalkulus berbantuan software geogebra yang telah dihasilkan telah terjawab yaitu berkualitas baik dan sangat baik sehingga layak untuk digunakan.

b. Uji Coba

Uji coba diterapkan di kelas A program studi fisika mata kuliah Kalkulus yang berjumlah 30 orang. Perangkat hasil validasi diberikan ke setiap mahasiswa dengan 2 kali pertemuan untuk pembagian LKm dan 2 kali pertemuan pembahasan jawaban dari setiap pertanyaan pada LKM. Dalam proses pembelajaran, siswa dikelompokkan 3-4 orang siswa yang terdiri dari siswa berkemampuan tinggi, sedang dan rendah. Sehingga kemampuan setiap kelompok dapat diasumsikan heterogen. Setelah itu mereka mengerjakan LKS untuk setiap siswa, dengan memberitahu terlebih dahulu bahwa di dalam kelompok bisa berkerja sama menjawab soal namun harus dipastikan seluruh anggota kelompok memahami jawaban yang diberikan. Siswa mengerjakan LKM-1 dan 2 dengan menggunakan 
media geogebra untuk membantu mereka memvisualkan berbagai grafik mengenai materi ajar.

\subsection{Analisis Data}

Analisis data dibutuhkan untuk menjawab rumusan masalah kedua dan ketiga pada penelitian ini. Berikit adalah hasil analisis inferesnial dan analisis deskriptif.

\subsubsection{Analisis inferensial}

Analisis akan menjawab rumusan masalah yang kedua yaitu apakah ada perbedaan sebelum dan sesudah pemberian LKM terhadap kemampuan spasial mahasiswa. Berikut hasil pengujian hipotesis menggunakan uji pairet $\mathrm{t}$ test:

Tabel 10 Paired Samples Test

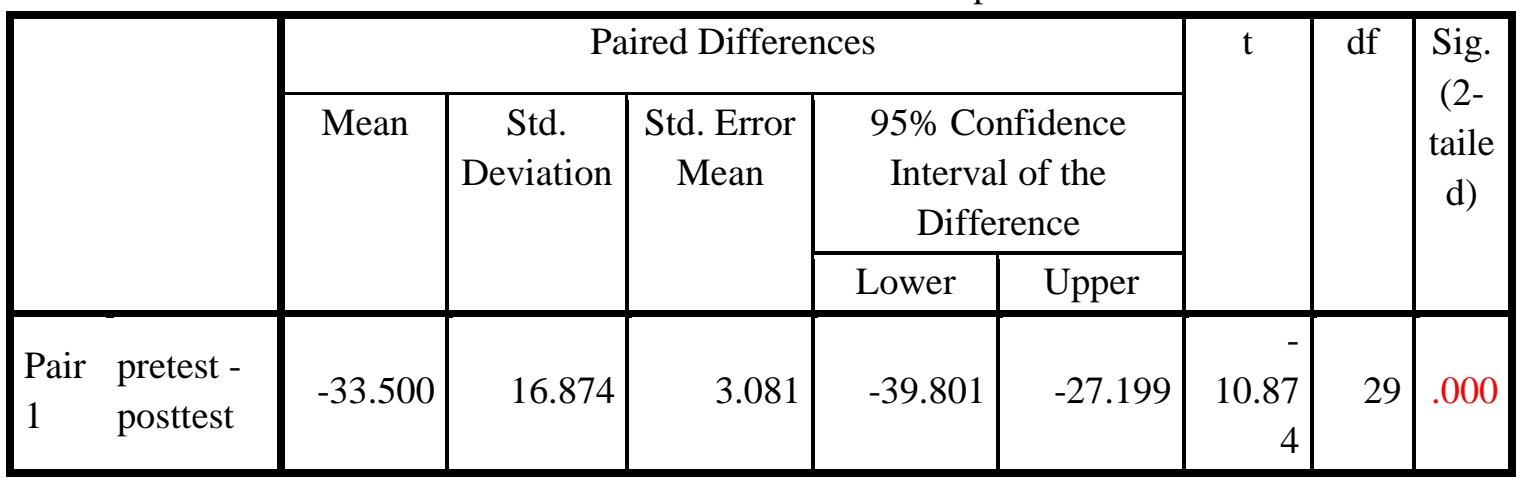

Diketahui nilai sig adalah $0.000<0.05$. Maka dapat disimpulkan menolak H0 dan menerima $\mathrm{H} 1$ berarti ada perbedaan sebelum dan sesudah pemberian LKM terhadap kemampuan spasial mahasiswa. Kemudian perbedaan nya seperti apa, akan dijawab melalui analisis deskriptif untuk menjawab rumusan masalah yang ketiga yaitu Bagaimana peningkatan kemampuan spasial mahasiswa berbantuan software GeoGebra dengan menggunakan LKM pada mata kuliah Kalkulus.

\subsubsection{Analisis deskriptif}

Data yang dianalisis adalah nilai pretest dan posttest mahasiswa. Kemudian mencari nilai gain atau selisih antara pretest dan posttest berdasarkan rumus yang telah diuraikan. Setelah itu menggunakan SPSS 20 untuk menganalisis nilai gain menggunakan one sample t test.

Analisis data menggunakan one sample $t$ test SPSS 20, berikut adalah hasil analisisnya:

Tabel 12 One-Sample Statistics

\begin{tabular}{|l|r|r|r|c|}
\hline & $\mathrm{N}$ & Mean & Std. Deviation & $\begin{array}{c}\text { Std. Error } \\
\text { Mean }\end{array}$ \\
\hline Gain & 30 & .50480652 & .240612153 & .043929568 \\
\hline
\end{tabular}


Mean: 0.5 berarti berada pada tingkat sedang. Nilai gain di analisis menggunakan One sample $\mathrm{t}$ test. Berdasarkan hasil analisis diatas menunjukkan peningkatan kemampuan spasial mahasiswa dengan mean 0.50 yang berada pada rentang $0.3<$ g $<0.7$ yang berkategori sedang. Sehingga dapat disimpulkan bahwa peningkatan kemampuan spasial setelah diberikan LKM berbantuan software GeoGebra adalah berkategori sedang.

\section{KESIMPULAN}

1. LKM yang telah dikembangkan berkategori baik dan sangat baik sesuai hasil validasi oleh ahli sehingga layak untuk digunakan dalam proses pembelajaran di kelas

2. Terdapat perubahan sebelum dan sesudah penggunaan LKM terhadap hasil belajar untuk meningkatkan kemampuan spasial mahasiswa

3. Penggunaan LKM berbantuan software GeoGebra dapat meningkatkan kemampuan spasial mahasiswa dengan berkategori sedang.

\section{DAFTAR PUSTAKA}

Battista, M.T. and Clements, D.H. (1998) "Students' Spatial structuring of 2D arrays of Sqaures". Journal for Research in Mathematics Education, 29 (5) 503-532

Hake, R, R. (1999). Analyzing Change/Gain Scores.AREA-D American Education Research Association's Devision.D, Measurement and Reasearch Methodology.

Lohman, D.F. (1993) Spatial Ability and G. Paper presented at the First Spearman Seminar, University of Plymouth, July 21, 1993

Linn, M.C. and Petersen, A.C. (1985) "Emergence and Characterization of Sex Differences in Spatial Ability: A-Meta Analysis". Child Development, Vol. 56, pp. 1479- 1498.

McGee, M.G. (1979). Human Spatial Abilities : Sources of Sex Differences. New York: Praeger

Oklun, S., (2003) 'Making Connections: Improving Spatial Abilities with Engineering Drawing Activities'. Int. Journ.of Mathematics Teaching and Learning.

Tartre, L.A. (1990) "Spatial Orientation Skill and Mathematical Problem Solving". Journal for Research in Mathematics Education, 21 (3) 216-229.

Piaget, J., \& Inhelder, B. (1956). The child's conception of space. London: Routledge \& Kegan Paul.

Gardner, H. (1983). Frames of mind: The theory of multiple intelligences . New York: Basic Books.

McGee, M. G. (1979). Human spatial abilities: Psychometric studies and environmental, genetic, hormonal and neurological infl uences. Psychological Bulletin, 86 , 899918. 